\title{
Editorial: El Niño-Southern Oscillation on a Changing Planet: Consequences for Coastal Ecosystems
}

\author{
José M. Riascos ${ }^{1,2 *}$, Dimitri Gutiérrez ${ }^{3,4}$, Rubén Escribano ${ }^{5}$ and Sven Thatje ${ }^{6}$ \\ ${ }^{1}$ Corporación Académica Ambiental, Universidad de Antioquia - Sede Ciencias del Mar, Turbo, Colombia, ${ }^{2}$ CEMarin - \\ Corporation Center of Excellence in Marine Sciences, Bogotá, Colombia, ${ }^{3}$ Dirección General de Investigaciones \\ Oceanográficas y de Cambio Climático, Instituto del Mar del Perú (IMARPE), Callao, Peru, ${ }^{4}$ Programa de Maestría en \\ Ciencias del Mar, Universidad Peruana Cayetano Heredia, Lima, Peru, ${ }^{5}$ Departamento de Oceanografía, Facultad de \\ Ciencias Naturales y Oceanográficas, Instituto Milenio de Oceanografía, Universidad de Concepción, Concepción, Chile, \\ ${ }^{6}$ National Oceanography Centre, University of Southampton, Southampton, United Kingdom
}

Keywords: climate variability, coastal ecosystems, Eastern boundary currents, biological impacts, oceanographic processes, marine ecology

\section{Editorial on the Research Topic}

\section{El Niño-Southern Oscillation on a Changing Planet: Consequences for Coastal Ecosystems}

With its warm (El Niño; EN) and cold (La Niña; LN) phases and its strong connection with the atmosphere through the Southern Oscillation pressure system, El Niño-Southern Oscillation (ENSO) represents the largest signal in the interannual ocean/climate variation (Wang et al., 1999). Owing to its massive global ecological and economic impacts (Golnaraghi and Kaul, 1995),

\section{OPEN ACCESS}

Edited and reviewed by: Iris Eline Hendriks,

University of the Balearic Islands, Spain

${ }^{*}$ Correspondence: José M. Riascos jose.riascos@udea.edu.co

Specialty section:

This article was submitted to Global Change and the Future Ocean,

a section of the journal

Frontiers in Marine Science

Received: 06 November 2019 Accepted: 29 November 2019 Published: 20 December 2019

Citation:

Riascos JM, Gutiérrez D, Escribano $R$ and Thatje S (2019) Editorial: E Niño-Southern Oscillation on a Changing Planet: Consequences for

Coastal Ecosystems.

Front. Mar. Sci. 6:774

doi: 10.3389/fmars.2019.00774 understanding how ENSO will respond to ongoing greenhouse warming has been a challenging question for climate scientists. Climate projections show that extreme EN-LN episodes are likely to occur more frequently with unabated greenhouse gas emissions (Cai et al., 2015; Wang et al., 2019). However, ocean climatic regimes and marine ecosystems are directly or indirectly modified by a wider array of ocean and land-based human activities, including pollution, resource harvesting, increased nutrient input, habitat destruction, and ocean sprawling (Halpern et al., 2008). Thus, we should expect that ENSO dynamics will interact with multiple human-related modifications in coastal systems.

The so-called Eastern Boundary Upwelling Systems (EBUS) are special coastal systems, not only because they are the most biologically productive marine regions (Pauly and Christensen, 1995) but also because of the direction of the likely effects of climate change. Model projections and observational data suggest a deoxygenation trend and the intensification of coastal upwelling-favorable winds in poleward portions in these systems (Levin, 2018), but there is low confidence regarding the future effects of climate change on coastal temperatures and biogeochemistry in EBUS (García-Reyes et al., 2015). Thus, it is key to deepen our understanding of biochemical processes of coastal waters under contrasting climatic regimes. In this context, this Research Topic provides a forum to discuss recent advances in understanding the consequences of ENSO dynamics for biological systems and biochemical processes within upwelling systems of the Americas.

The collection of articles presented in this Research Topic illustrates the interaction of ENSO dynamics with (i) human-related stresses and its effect on biological processes of coastal species and (ii) biogeochemical processes of the Oxygen Minimum Zone in two major EBUS-the Humboldt and California upwelling systems.

The first three articles deal with responses of mollusk consumers to ENSO and other interacting 
stressors. Pelagic mollusks (pteropods) are important food sources and key indicators of ocean acidification in upwelling systems. Bednaršek et al. assess the cellular to physiological and population responses of the pteropod Limacina helicita to the interaction effect of EN episodes and ocean acidification in the California Current system. Their study established a link between lowered $\mathrm{pH}$ and aragonite saturation state and enhanced oxidative stress for pteropods and suggest that oxidative stress biomarkers are early-warning signals of multiple stressors on the cellular level.

Understanding the factors and mechanisms driving changes in larval settlement and recruitment is a prerequisite for management and conservation of exploited species in highly productive systems. Using a 9-yr dataset, Solís et al. describe the transition between gamete release, larval settlement and subsequent recruitment of the bivalve Aulacomya atra from Bahía Independencia (Peru) and show that these are affected by human exploitation and modulated by El Niño-La Niña episodes. In turn, Avendaño et al. present an article on earlylife population processes of the Peruvian scallop (Argopecten purpuratus) through El Niño and La Niña episodes in a marine reserve, showing that a long-term decrease of settlement surfaces plays a key role in explaining the collapse of natural stocks of this consumer in northern Chile.

The last three articles deal with Oceanographic processes and ENSO: Jiménez-Quiroz et al. present data on an unusual warming period called "The Blob" and EN in the southwestern Baja California peninsular plankton ecosystem, and demonstrate that the phenology of phytoplankton and zooplankton changes after the strong perturbation caused by the El Niño, and possibly The Blob. Espinoza-Morriberón et al. study the physical and biogeochemical processes in the Tropical South Eastern Pacific

\section{REFERENCES}

Cai, W., Santoso, A., Wang, G., Yeh, S. W., An, S. I., Cobb, K. M., et al. (2015). ENSO and greenhouse warming. Nat. Climate Change 5:849. doi: $10.1038 /$ nclimate 2743

García-Reyes, M., Sydeman, W. J., Schoeman, D. S., Rykaczewski, R. R., Black, B. A., Smit, A. J., et al. (2015). Under pressure: climate change, upwelling, and eastern boundary upwelling ecosystems. Front. Mar. Sci. 2:109. doi: $10.3389 /$ fmars.2015.00109

Golnaraghi, M., and Kaul, R. (1995). The science of policymaking: Responding to ENSO. Environ. Sci. Policy Sustain. Dev. 37, 16-44.

Halpern, B. S., Walbridge, S., Selkoe, K. A., Kappel, C. V., Micheli, F., D'agrosa, C., et al. (2008). A global map of human impact on marine ecosystems. Science 319, 948-952. doi: 10.1126/science.1149345

Levin, L. A. (2018). Manifestation, drivers, and emergence of open ocean deoxygenation. Annu. Rev. Mar. Sci. 10, 229-260. doi: 10.1146/annurev-marine-121916-063359

Pauly, D., and Christensen, V. (1995). Primary production required to sustain global fisheries. Nature 374, 255-257. doi: 10.1038/374255a0 associated with the subsurface oxygen variability during EN and LN in the period 1958-2008. They demonstrate that enhanced mesoscale variability during EN impacts Oxygen Minimum Zone ventilation through horizontal and vertical eddy fluxes. Igarza et al. evaluate dissolved organic matter cycling in the coastal upwelling system off central Peru during EN and show that even under low productivity conditions that characterizes EN episodes, there is an active cycling of the dissolved organic matter pool off central Peru.

The collection of articles in this Research Topic emphasizes that the identification of biological and biochemical consequences of ENSO may be elusive and demands an understanding of the interaction of ENSO dynamics with the whole array of human-related alterations in coastal upwelling systems.

\section{AUTHOR CONTRIBUTIONS}

All authors listed have made a substantial, direct and intellectual contribution to the work, and approved it for publication.

\section{FUNDING}

Funding grant provided by SCOR (Scientific Committee for Oceanic Research) to conduct international collaborative research on eastern boundary upwelling systems (EBUS). Two co-authors RE and DG are part of this project.

\section{ACKNOWLEDGMENTS}

We thank all the contributors to this Research Topic.

Wang, B., Luo, X., Yang, Y. M., Sun, W., Cane, M. A., Cai, W., et al (2019). Historical change of El Niño properties sheds light on future changes of extreme El Niño. Proc. Natl. Acad. Sci. U.S.A. 116, 22512-22517. doi: 10.1073/pnas.1911130116

Wang, H. J., Zhang, R. H., Cole, J., and Chavez, F. (1999). El Niño and the related phenomenon Southern Oscillation (ENSO): the largest signal in interannual climate variation. Proc. Natl. Acad. Sci. U.S.A. 96, 11071-11072.

Conflict of Interest: The authors declare that the research was conducted in the absence of any commercial or financial relationships that could be construed as a potential conflict of interest.

Copyright (c) 2019 Riascos, Gutiérrez, Escribano and Thatje. This is an open-access article distributed under the terms of the Creative Commons Attribution License (CC $B Y)$. The use, distribution or reproduction in other forums is permitted, provided the original author(s) and the copyright owner(s) are credited and that the original publication in this journal is cited, in accordance with accepted academic practice. No use, distribution or reproduction is permitted which does not comply with these terms. 